\title{
PERAN PENGASUH PANTI ASUHAN YAYASAN MELATI ALKHAIRAT AMBON DALAM MENINGKATKAN PRESTASI BELAJAR ANAK ASUH
}

\author{
Kasim Hukul ${ }^{1}$, St. Jumaeda ${ }^{2}$, Saddam Husein ${ }^{3}$ \\ ${ }^{1}$ Mahasiswa PAI FITK IAIN Ambon, ${ }^{2}$ Dosen PAI FITK IAIN Ambon, Dosen PAI FITK IAIN \\ Ambon $^{3}$ \\ Email: saddam@iainambon.ac.id
}

\begin{abstract}
Abstrak penelitian ini memfokuskan permasalahan pada bagaimana peran pengasuh panti asuhan Yayasan Melati Alkhairat dalam memberikan bimbingan, motivasi dan menjadi fasilitator bagi anak asuh pada tingkat SMA Kelas $X$ ? Tujuan dari penelitian ini adalah untuk mengetahui peran pengasuh panti asuhan Yayasan Melati Alkhairat Ambon dalam Meningkatkan prestasi Belajar Anak Asuh. Tipe penelitian yang digunakan adalah penelitian kualitatif yakni penelitian dengan mendefinisikan konsep-konsep yang sangat umum, dan mencari pola-pola hubungan antara konsep tersebut. Penelitian ini juga bersifat deskriptif karena bertujuan menggambarkan dan menjelaskan secara lengkap mengenai permasalahan yang diangkat dalam penelitian ini. Subjek dalam penelitian ini adalah orang tua asuh yang berada di panti asuhan Melati Alkhairat Ambon yang berjumlah 3 orang. Instrumen penelitian yang digunakan adalah wawancara dan observasi yang dianalisis secara kualitatif. Hasil penelitian menunjukkan bahwa peran pengasuh panti asuhan Yayasan Melati Alkhairat Ambon dalam meningkatkan prestasi belajar anak asuh,1) pengasuh menggantikan peran orang tua sehingga anak-anak tidak merasa seperti orang asing dan menganggap pengasuh sebagai orang tua mereka, 2) pengasuh berusaha mendatangkan ustadz dan ustazah, yang dengan ikhlas mau membagikan ilmu mereka kepada anak-anak asuh sehingga menambah wawasan kepada mereka, 3) pengasuh memberikan nasehat dan mendorong anak asuh untuk belajar lebih giat mengejar cita-cita masa depan, 4) mengontrol jam belajar anak asuh, 5) memberikan motivasi, 6) menjadi fasilitator bagi anak asuh. Adapun faktor pendukung pengasuh dalam meningkatkan prestasi belajar anak asuh adalah mendapatkan bantuan berupa dana dari berbagai pihak untuk keperluan sekolah mereka, faktor penghambat ialah masih kekurangan tenaga pengasuh, sarana-prasarana kurang memadai, letak panti asuhan yang berada di tengah-tengah masyarakat menjadi kurang efektif. Hasil belajar anakanak asuh sangat baik dibuktikan dengan sertifikat yang diberikan oleh pihak sekolah kepada salah satu anak asuh yang masuk dalam peringkat sepuluh besar.
\end{abstract}

Kata Kunci : Peran Pengasuh, Meningkatkan Prestasi Belajar 


\section{PENDAHULUAN}

Panti asuhan Yayasan melati Alkhairat merupakan sebuah lembaga yang menampung anak-anak yatim, piatu, dan yatim piatu, serta anak-anak yang kurang mampu, dimana anak-anak tersebut dididik dan dikembangkan potensi yang mereka miliki untuk bekal mereka mengarungi hidup. Mereka anak-anak yatim, piatu, dan yatim piatu yakni anak-anak yang telah putus hubungan dengan kedua orang tuanya. Tujuan yaitu untuk mensejahterakan anak-anak asuhnya, kesejahtraan yang dimaksud adalah agar anak tersebut tetap memperoleh haknya yaitu, memperoleh kehidupan yang layak khususnya mengenai pendidikannya, baik itu pendidikan formal maupun informal seperti halnya anak-anak normal lainnya yang masih memiliki kedua orang tua dan merasakan hidup yang layak dan berkecukupan (Khatib Ramyulis, 1996). Anakanak asuh Panti Asuhan Yayasan Melati Alkhairat memiliki latar belakang keluarga yang hampir sama yaitu mereka hanya memiliki salah satu orang tua bahkan tidak memiliki kedua orang tua sama sekali.

Berdasarkan hasil observasih awal di Panti Asuhan Yayasan Melati Alkhairat masih terdapat berbagai anak asuh yang motivasi belajarnya rendah, dan hal-hal yang lainnya.

Dari konteks penelitian tersebut di atas, maka bermaksud mengadakan penelitian mengenai Peran pengasuh Panti Asuhan Yayasan Melati Alkhairat Dalam Meningkatkan Prestasi Belajar Anak Asuh Tingkat SMA.

\section{TINJAUAN PUSTAKA}

\section{A. Peran Pengasuh Panti Asuhan}

\section{Peran Pengasuh}

Berbicara mengenai peran, tentu tidak dilepaskan dengan status (kedudukan). Walaupun keduanya berbeda, akan tetapi saling berhubungan erat antara yag satu dengan yang lainya, semua diibaratkan seperti dua sisi mata uang yang berbeda, akan tetapi keikatannya akan sangat terasa sekali. Seseorang dikatakan berperan atau memiliki peran karena orang tersebut mempunyai status dalam masyarakat, akan tetapi masing-masing individu berperan dengan statusnya.

\section{Peran Pengasuh Panti Asuhan}

pengasuh adalah bentuk perlakuan atau tindakan pengasuh memelihara, melindungi, mendampingi, mengajar dan membimbing anak selama masih perkembangan. Pengasuhan berasal dari asuh yang mempunyai makna menjaga, merawat, mengajar dan mendidik anak.

Menurut wagnel dan Funk bahwa mengasuh itu meliputi menjaga serta memberi bimbingan menuju pertumbuhan kearah kedewasaan dengan memberikan pendidikan, makanan dan sebagainya terhadap mereka yang diasuh (Sunartik, 1989). Peran pengasuh panti asuhan yaitu mengambil ahli peran yang ditinggalkan orang tua si yatim, piatu atau yatim piatu agar mereka bisa menemukan jati diri, memelihara, mendidik dengan penuh pengertian dan mampu mengembangkan potensi dan bakat, mandiri dan berguna. 


\section{Panti Asuhan}

Menurut (Depsos Pedoman Depsos RI, 1986). Panti Sosial Asuhan Anak adalah suatu lembaga usaha kesejahtraan sosial yang mempunyai tanggung jawab untuk memberikan pelayanan kesejahtraan sosial pada anak terlantar dengan melaksanakan penyantunan dan pemeliharaan anak terlantar, memberikan pelayanan pengganti orang tua/wali anak dalam memenuhi kebutuhan fisik, mental, dan sosial kepada anak asuh sehingga memperoleh kesempatan yang luas, tepat, dan memadai bagi pengembangan kepribadiannya sesuai dengan yang diharapkan sebagai bagian dari generasi penerus cita-cita bangsa dan sebagai insan yang akan turut serta aktif dalam bidang pembangunan nasional.

\section{Tujuan Panti Asuhan} yaitu:

Tujuan panti asuhan menurut Departemen Sosial Republik Indonesia

a. Panti asuhan memberikan pelayanan yang berdasarkan pada profesi pekerja sosial kepada anak terlantar dengan cara membantu dan membimbing mereka ke arah perkembagan pribadi yang wajar serta mempunyai keterampilan kerja, sehingga mereka menjadi anggota masyarakat yang dapat hidup layak dan penuh tanggung jawab, baik terhadap dirinya, keluarga dan masyarakat.

b. Tujuan penyelenggaraan pelayanan kesejahtraan sosial anak di panti asuhan adalah terbentuknya manusia-manusia yang berkepribadian matang dan dedikasi, mempunyai keterampilan kerja yang mampu menopang hidupnya dan keluarganya.

\section{Fungsi Panti Asuhan}

Menurut Departemen Social Republik Indonesia, panti asuhan memeliki fungsi sebagai berikut :

a. Pusat pelayanan kesejahtraan sosial anak. Panti asuhan berfungsi sebagai pemulihan, perlingdungan, pengembangan dan pencegahan.

b. Pusat data dan informasih serta konsultasi kesejahtraan sosial anak.

c. Pusat pengembangan keterampilan (yang merupakan fungsi penunjang).

d. Panti asuhan sebagai lembaga yang melaksanakan fungsi keluarga dan masyarakat dalam perkembangan dan kepribadiaan anak-anak remaja.

\section{B. Tinjauan Tentang Prestasi Belajar}

\section{Pengertian Prestasi Belajar}

Kata "Prestasi" berasal dari bahasa belanda yaitu prestatie kemudian dalam bahasa Indonesia menjadi "prestasi" yang berarti hasil usaha (Zainal Arifin, 1991). Prestasi belajar adalah penguasaan pengetahuan atau keterampilan yang dikembangkan oleh mata pelajaran, lazimnya ditunjukkan dengan nilai yang diberikan oleh guru.

Prestasi belajar dapat dirumuskan sebagai berikut.

a. Prestasi belajar siswa adalah hasil belajar yang dicapai siswa ketika mengikuti dan mengerjakan tugas dan kegiatan pembelajaran di sekolah.

b. Prestasi belajar siswa tersebut terutama dinilai aspek kognitifnya karena yang bersangkutan dengan kemampuan siswa dalam pengetahuan atau ingatan, pemahaman, aplikasih, analisis, sistesa dan evaluasi. 
c. Prestasi belajar siswa dibuktikan dan ditunjukkan melalui nilai dari hasil evaluasi yang dilakukan oleh guru terhadap tugas siswa dan ulanganulangan atau ujian yang ditempuhnya.

\section{Faktor-faktor Belajar Internal dan Eksternal Dalam Mempengaruhi Prestasi Belajar Anak.}

Belajar internal adalah masalah-masalah yang timbul dari dalam diri siswa atau faktor-faktor internal yang menimbulkan kekurangan siswa dalam belajar. Sedangkan faktor eksternal adalah segala faktor yang ada di luar diri siswa yang memberikan pengaruh terhadap aktivitas dan hasil belajar yang dicapai siswa (Nyayu Khodijah, 2014). Faktor intrenal adalah faktor yang ada dalam diri individu yang sedang belajar. Yang termasuk dalam faktor intrenal seperti faktor jasmaniah, faktor psikologi dan faktor kelelahan. Sedangkan faktor eksternal yang berpengaruh terhadap belajar, dapat dikelompokan menjadi tiga faktor yaitu, faktor keluarga, faktor sekolah (organisasi) dan faktor masyarakat. Berikut ini faktor internal dan eksternal.

\section{METODE PENELITIAN}

Pendekatan penelitiaan yang digunakan dalam penelitian ini adalah pendekatan penelitian kualitatif. Dan sumber data primer dan sekunder. Dengan prosudur pengumpulan data dengan menggunakan metode-metode berikut, observasi, wawancara, dokumentasih. Adapun teknik analisis data yaitu reduksi data, penyajian data dan verfikasih, untuk mengetahui peran pengasuh panti asuhan yayasan melati alkhairat dalam meningkatkan prestasi belajar anak asuh, serta faktor pendukung dan penghambat dalam meningkatkan prestasi belajar, dan hasil belajar anak-anak asuh. Teknik wawancara yang digunakan yaitu purposive sampling informan ditentukan oleh penulis sendiri agar mendapatkan informan yang sesuai dengan tujuan peneliti agar mendapatkan data yang akurat.

\section{PEMBAHASAN}

\section{Peran Pengasuh Panti Asuhan Yayasan Melati Alkhairat Ambon Dalam Meningkatkan Prestasi Belajar Anak Asuh}

Anak asuh yang dititipkan di Panti Asuhan Melati Alkhairat Ambon berasal dari keluaraga yang beragam latar belakangnya. Baik latar belakang ekonomi, sosiologis, maupun latar belakang kultural. Secara ekonomi seluruhnya mereka memiliki latar belakang ekonomi lemah atau kurang mampu, kurang mampu yang dimaksudkan disini adalah kurang mampu dalam memenuhi kebutuhan pendidikan bagi anak-anaknya. Disamping itu, ada juga yang suda yatim, piatu atau bahkan yatim piatu sehingga mereka dititipkan oleh kedua orang tua kandung, kakak, keluarga maupun sanak saudara ke Panti Asuhan agar mereka mendapatkan pendidikan yang layak, baik pendidikan agama maupun pendidikan umum. Mereka dititipkan juga dengan maksud agar dapat mengurangi beban ekonomi bagi keluarga yang tidak mampu sama sekali dalam memenuhi kebutuhan hidup sehari-hari, sehingga solusi menitipkan anak ke Panti Asuhan merupakan cara yang sangat tepat. 
Banyak bentuk aktualisasi peran pengasuh dalam mendidik dan membina serta mendorong anak asuh agar menjadi orang yang bermanfaat kepada masyarakat, bangsa dan negara. Penanaman nilai-nilai keagamaan yang kuat dan sistematis ditujukan untuk menyiapkan anak asuh agar dapat berperan penting bagaimana layaknya peran-peran orang dengan latar belakang bukan anak asuh dalam Panti Asuhan.

Pendalaman pendidikan akhlak dan moral yang baik melalui ceramahceramah keagamaan, pendidikan dan pelatihan mental spiritual, nasehat dan bimbingan praktis dalam fokus kehidupan sangat perlu didapatkan anak asuh, sebagai bagian penting peran pengasuh yang harus dilaksanakan. Menjelang shalat ashar, mereka sudah bangun dari tidur siang dan bersiap-siap mengerjakan sholat ashar. Selesai mengerjakan shalat ashar, mereka melanjutkan dengan pengajian dan kultum setelah mereka menyelesaikan hal terseebut, ada yang bermain-main di halaman Panti, ada yang bermain bola kaki, bola voli dan lain-lain.

Selesai bermain-main, anak asuh mandi dan bersiap-siap untuk mengerjakan shalat magrib berjamaah di mushalla dan selesai mengerjakan shalat magrib berjamaah, anak asuh mendengarkan nasehat-nasehat, ceramah-ceramah dan kata-kata bijak yang diberikan oleh orang tua asuh. Kadang-kadang, nasehat dan siraman rohani diberikan oleh ustad yang didatangkan oleh pihak panti dari luar. Ceramah agama yang diberikan dilanjutkan dengan shalat isya berjamaah. Kadang-kadang selesai shalat isya pegasuh juga memberikan sedikit motivasi kepada anak asuh untuk berbuat kebaikan, belajar yang tekun agar menjadi anak bermanfaat bagi masyarakat, bangsa dan negara.

Motivasi sangat diperlukan dalam belajar, sebab seseorang yang tidak mempunyai motivasi dalam belajar, tak akan mungkin melakukan aktivitas belajar. Hal ini merupakan pertanda bahwa sesuatu yang menarik minat orang lain belum tentu menarik minat orang tertentu selama sesuatu itu tidak bersentuhan dengan kebutuhannya. Maslow sangat percaya bahwa tingkah laku manusia dibangkitkan dan diarahkan oleh kebutuhan-kebutuhan tertentu, seperti kebutuhan fisiologis, rasa aman, rasa cinta, penghargaan, aktualisasi diri, mengetahui dan mengerti, dan kebutuhan estetik.

Kebutuhan-kebutuhan inilah menurut Maslow yang mampu memotivasi tingkah laku individu. Oleh karena itu, apa yang seseorang lihat sudah tentu akan membangkitkan minatnya sejauh apa yang ia lihat itu mempunyai hubungan dengan kepentingannya sendiri (Sardiman, 2012).

Dalam kegiatan belajar peran motivasi sangat diperlukan. Motivasi bagi orang yang sedang belajar dapat mengembangkan aktivitas dan inisiatif, dapat mengarahkan dan memelihara ketekunan dalam melakukan kegiatan belajar untuk mencapai prestasi yang tinggi. Motivasi akan meyebabkan terjadinya suatu perubahan energi yang ada pada diri manusia, sehingga akan mempengaruhi persoalan gejala kejiwaan, perasaan dan juga emosi, untuk kemudian bertindak atau melakukan sesuatu. Semua ini didorong karena adanya tujuan, kebutuhan atau keinginan.

Motivasi dapat berperan dalam penguatan belajar apabila seorang anak yang belajar dihadapkan pada suatu masalah yang memerlukan pemecahan, dan hanya dapat dipecahkan berkat bantuan hal-hal yang pernah dilaluinya.

Peran motivasi dalam memperjelas tujuan belajar erat kaitannya dengan kemaknaan belajar. Anak akan tertarik untuk belajar sesuatu, jika yang 
dipelajari itu setidaknya sudah dapat diketahui atau dinikmati manfaatnya bagi anak. Seorang anak yang telah termotivasi untuk belajar sesuatu, akan berusaha mempelajarinya dengan baik dan tekun, dengan harapan memperoleh hasil yang baik. Dalam hal ini, tampak bahwa motivasi untuk belajar menyebabkan seseorang tekun belajar.Sebaliknya, apabila seseorang kurang atau tidak memiliki motivasi untuk belajar, maka dia tidak tahan lama belajar. Dia mudah tergoda untuk mengerjakan hal yang lain dan bukan belajar. Itu berarti motivasi sangat berpengaruh terhadap ketahanan dan ketekunan belajar.

Dengan motivasi yang diberikan pengasuh kepada mereka, mereka belajar tekun untuk menjadi manusia terbaik yang bermanfaat bagi masyarakat bangsa dan negara serta agama. Strategi memotivasi anak asuh yang paling tepat dalam mendorong semangat belajar anak asuh di Panti Asuhan Melati Alkhairat Ambon adalah dengan memberikan nasehat, pemberian pengawasan, pemenuhan fasilitas belajar, pemberian hadiah, pemberian penghargaan.

Pemberian pengawasan yang dilakukan oleh pengasuh kepada anakanak asuh di panti asuhan Yayasan Melati Alkhairat berupa menanyakan hasil belajar, menanyakan tugasnya yang diberikan oleh guru, membagi waktunya, mengawasih anak-anak belajar.

Pemberian fasilitas belajar yang diberikan oleh pengasuh panti asuhan Yayasan Melati Alkhairat kepada anak-anak asuh berupa perlengkapan sekolah, seperi alat-alat tulis, dan buku-buku pelajaran. Pemberian penghargaan sangat dibutuhkan oleh seorang anak untuk memotivasinya agar mengulangi untuk melakukan suatu perilaku yang baik dan anak juga merasah bahwa tindakan dan usahanya dinilai dan dihargai oleh pengasuh, pemberian pengahargaan yang diberikan oleh pengasuh kepada anak berupa kata-kata yang mnyenangkan hati anak, memberikan pujian, memerintahkan anak agar mempertahankan prestasinya.

Adapun juga pemberian hadiah yang diberikan oleh pengasuh kepada anak asuh berupa uang saku bagi anak yang hasil belajarnya baik, cara yang digunakan pengasuh untuk dapat memotivasi belajar anak asuh sangatlah baik dan inilah yang diharapkan oleh anak asuh dalam panti.

Namun Pemberian sangsi/hukuman oleh pengasuh kepada anak asuh yang tidak mengikuti aturan yang ditetapkan oleh pihak panti, meliputi pemberian hukuman ketika anak tidak mengikuti pembinaan berupa pengajian, pemberian hukuman oleh pengasuh berupa menesehati akan pentingnya pendidikan untuk masah depan mereka, sehingga anak-anak tidak lagi melanggar aturan yang dibuat oleh pihak panti asuhan. Ini bukan saja sekedar cara untuk mendorong anak asuh untuk giat belajar, tetapi juga merupakan kewajiban bagi orang tua asuh, dalam membina agar anak dapat mengikuti semua rangkain aturan yang ada pada panti.

Bimbingan dan didikan yang diberikan oleh pengasuh kepada anak asuh di Panti Asuhan Melati Alkhairat Ambon dilakukan sebagai upaya sadar pengasuh untuk dapat mempersiapkan anak-anak asuh ini menjadi baik dan berguna bagi diri sendiri dan orang lain sebagaimana tertuang dalam visi dan misi, serta mereka dapat memiliki masa depan yang baik guna menjalankan tugas mereka sebagai khalifah di muka bumi. Kelak suatu saat mereka akan keluar dari Panti Asuhan dan melanjutkan kehidupan yang lebih baik dan mandiri, menemukan jodoh, menikah, berkeluarga dan melanjutkan misi 
mempertahankan habitat anak adam di dunia. Mereka akan hidup mandiri tanpa harus bersandar lagi pada orang lain, mereka harus bekerja untuk bertahan hidup.

Dengan pendidikan yang diperoleh di Panti Asuhan, mental, akhlak, budi pekerti dan keahlian mereka dapat di asah dan ditingkatkan, sebagai bekal anak asuh dalam mempertahankan hidup. Usaha pengasuh yang dilakukan, dilakukan dengan penuh kesadaran dan tanggung jawab mereka sebagai pengasuh di Panti Asuhan.

Selaku pengasuh yang bertanggung jawab terhadap anak asuhan, pengasuh selalu memberikan motivasi berupa nasehat-nasehat tentang kebaikan, melaksanakan amar maruf nahi mungkar, mengerjakan shalat, membaca al-qur'an setelah selesai shalat dan lain sebagainya. Disamping itu, sering juga dilakukan kajian-kajian atau ceramah-ceramah agama yang diberikan oleh ustadz dan ustadzah yang diundang oleh pihak Panti Asuhan. Nasehatnasehat untuk selalu belajar dengan tekun, mengerjakan tugas-tugas rumah dengan baik, sehingga hasil belajar mereka meningkat dengan baik di sekolah, menjadi dorongan besar bagi anak asuh untuk belajar mengejar cita-cita tinggi di masa datang dan dengan tujuan mulia agar kedua orang tua mereka menjadi bangga dan berbahagia dengan prestasi belajar yang di dapatkan selama tinggal di panti asuhan, belajar, memperoleh pendidikan, baik agama maupun pendidikan umum. Pendidikan agama sangat penting diberikan kepada anak asuh agar anak asuh dapat menjadi berguna layaknya anak manusia yang hidup dari keluarga yang berkecukupan secara ekonomi dan yang masih memiliki orang tua. Pendidikan agama diberikan agar anak asuh dapat menjadi anak yang bermanfaat bagi diri sendiri dan orang lain. Pendidikan agama yang baik dan tepat, yang diberikan dengan penuh kesadaran dan dedikasi, tentu akan menghasilkan generasi berakhlak yang kuat dalam mempertahankan nilai-nilai keislaman dalam kehidupan di era modern masa kini.

Tanggung jawab sosial dan moral pengasuh terhadap anak asuh dalam mendidik, membesarkan dan membina mental, akhlak dan wawasan anak asuh sesungguhnya adalah pekerjaan mulia di sisi Allah Swt. Allah Swt akan mencatat segala kebaikan yang diberikan pengasuh kepada anak asuh, karena mereka telah memenuhi kebutuhan dasar anak asuh dengan penuh tanggung jawab. Pengasuh merasa senang dengan apa yang mereka lakukan dan berikan kepada anak asuh, mereka bangga melihat anak asuh menjadi manusia yang berguna bagi diri sendiri dan orang lain, senang dengan segala pencapaian yang didapat oleh anak asuh. Di satu sisi, anak asuh sangat senang dengan apa yang diberikan oleh pengasuh, bimbingan, dorongan dan pemenuhan kebutuhan yang diberikan orang tua asuh. Selama tinggal di Panti Asuhan, anak asuh sangat senang dan berbahagia. Di Panti Asuhan mereka mendapatkan pendidikan yang layak, tempat tinggal yang baik serta pergaulan dengan sesama anak asuh yang memberikan kesan tersendiri.

Selama di Panti Asuhan, anak asuh sangat bahagia karena pengasuh sangat baik kepada mereka, mereka (anak asuh) diperlakukan layaknya seorang ibu memperlakukan anak kandungnya. Mereka mendapatkan kasih sayang, dan anak-anak asuh merasa senang dengan kasih sayang yang diberikan oleh mereka. Dengan perasaan yang bahagi inilah yang mendasari anak asuh untuk menjalani hari-hari di Panti Asuhan dengan baik. Semua aktivitas, tugas dan tanggung jawab yang diberikan dilaksanakan dengan dorongan besar. Sehingga semua pekerjaan terlaksana dengan baik serta selesai sesuai waktu yang 
ditentukan. Mungkin anak asuh merasa bahwa mereka sebagai anak yang berasal dari keluarga yang tidak mampu, atau bahkan yang sudah tidak memiliki orang tua, dan tinggal di Panti Asuhan di bawah pengawasan, didikan, binaan dan tanggung jawab pengasuh, sehingga menjadikan mereka sebagai pribadi tekun dan rajin, yang bertanggung jawab terhadap tugas yang diberikan pengasuh. Selain itu, selama dalam proses penelitian, peneliti melihat bahwa perilaku anak asuh secara keseluruhan adalah cukup baik dan dapat disimpulkan bahwa mereka menyadari betul posisi dan kapasitas mereka sebagai anak asuh yang harus belajar tekun guna memiliki wawasan kehidupan yang lengkap dan kuat.

2. Faktor Pendukung dan Penghambat Dalam Meningkatkan Prestasi Belajar Anak Asuh

\section{a. Faktor Pendukung}

Faktor eksternal, mendapatkan dorogan positif dari berbagai pihak agar tercapainya sebuah pencapaian yang berdasarkan tujuan yang telah ditentukan. Sebuah lembaga tidaklah berproses dengan sendiri, melainkan membutukan berbagai bantuan dari berbagai pihak mana pun baik masyarakat ataupun pemerintah berupa dana, sehinggah pengasuh mempergunakan dana tersebut untuk keperluan sekolah mereka agar dapat melanjutkan Study mereka keperguruan Tinggi untuk meraih masah depan yang lebih baik.

Pengasuh berusaha mendatangkan para Ustadz dan Ustadzah mereka dengan ikhlas mau memberikan ilmu mereka kepada anak-anak asuh sehingga menambah wawasan kepada mereka.

Faktor internal, panti melakukan acara tahunan pada setiap tangal 31 desember, dengan diadakan berbagai macam lombah, yang berbasis islamic competetion, guna sebagai motivasi anak asuh dan evaluasi tahunan sejauh mana proses pembelajaran anak asuh, dan diadakan pemberian hadiah bagi anak yang memperoleh prestasi dan juarah, disisi lain agar anak juga tidak boleh mengikuti kegiatan akhir tahun dengan hal-hal yang melanggar norma dan kaidah dan berbaur dengan pergaulan yang tidak diinginkan oleh pihak panti maupun secara bermasyarakat, dengan mata lomba pada kegiatan tersebut meliputi lomba cerdas cermat mulai dari materi umum dan materimateri yang pernah diajarkan oleh pihak pengasuh secara umum, dan juga mata lomba berceramah, setiap anak asuh wajib mengikuti kegiatan tersebut agar membina jiwa dan raga secara mandiri, dan juga adapun mata lomba tahunan yang masih banyak diadakan oleh pihak panti.

Faktor eksternal, fungsi control yang dijalankan dengan baik oleh pengasuh, mengontrol merupakan tindakan dari pada tanggung jawab yang harus dilakukan, tanpa conrtol yang baik maka segala yang telah direncanakan akan berjalan tak terarah. Pengasuh yang diamankan untuk bertanggung jawab penuh akan hal itu tentunya menjalankan segala kewajibannya. Ketika fungsi control baik, maka segalanya akan dapat di kendalikan dengan baik tetapi jika controlnya tidak sesuai dengan tanggung jawab maka secara otomatis segala kegiatan akan tak sesuai dengan yang diharapkan.

Faktor internal, para anak-anak anak asuh yang semangat dalam belajar. Belajar merupakan suatu proses transfer pengetahuan dari satu pihak kepada pihak yang lain, tetapi jika dalam proses belajar itu hanya satu pihak yang mengiginkan berarti tidak akan berjalan sesuai dengan apa yang diharapkan atau inginkan. Dengan keadaan santri yang seperti itu maka tujuan tidak akan 
tercapai dengan baik, setiap anak pasti ada rasa senang dan jenuh dalam proses pembinaan tentunya.

\section{b. Faktor Penghambat}

Faktor eksternal, pembinaan dan bimbingan yang diberikan oleh pengasuh kepada anak asuh dirasakan belum maksimal, ini dikarenakan keterbatasan tenaga pembimbingan. Walaupun begitu, pengasuh dalam hal ini ketua yayasan Melati Alkhairat Ambon tetap berupaya memaksimal mungkin untuk memberikan pembinaan terbaik bagi anak asuhnya agar mereka menjadi manusia yang bermanfaat bagi manusia yang lain.

Masih kekurangan sarana prasarana dalam hal ini seperti tempat untuk anak-anak belajar, tempat untuk pembinaan dan lain sebagainya, Sarana prasarana adalah segala sesuatu yang merupakan penunjang utama terselengaranya suatu proses pembinaan. Dengan demikian, suatu proses kegiatan yang akan dilakukan tidak akan dapat mencapai hasil yang diharapkan sesuai dengan rencana, jika sarana dan prasaranya tidak memadai akan mempengaruhi kualitas belajar anak anak asuh dan pada akhirnya juga mempengaruhi hasil belajar anak-anak asuh.

Begitu juga dengan kondisi panti asuhan Yayasan Melati Alkhairat yang letaknya di tengah-tengah masyarakat sehingga anak-anak meniru kebiasaankebiasaan yang kurang baik dari lingkungan seperti pada saat jam pembinaan anak-anak asuh masih bermain dengan teman-temanya sehingga ditegur oleh pengasuh.

\section{Prestasi belajar anak-anak asuh panti asuhan Yayasan Melati Alkhairat}

Prestasi belajar merupakan tingkat kemampuan anak-anak yang dimilikinya dalam menerima, menolak dan menilai informasi-informasi yang diperoleh dalam proses belajar. Prestasi seseorang sesuai dengan tingkat kesungguhan dan keberhasilan seorang anak dalam mempelejari materi pelajaran. Prestasi belajar dapat diketahui setelah diadakan evaluasi.

prestasi belajar anak-anak asuh panti asuhan Yayasan Melati Alkhairat sangatlah baik yang dapat dilihat dari kecapaian hasil belajar yang mereka dapatkan berupa sertifikat yang diberikan oleh pihak sekolah kepada anak asuh yang masuk dalam peringkat (sepuluh besar) pada saat penerimaan laporan pendidikan, namun ada juga yang tidak memuaskan karena hasil belajar ana-anak mereka kurang baik, tetapi pengasuh selalu memberikan motivasi atau dorongan.

Motivasi atau dorongan kepada anak-anak yang hasil belajarnya sangat baik seperti pemberian hadiah berupa uang saku agar dapat mempertahankan atau meningkatkan hasil belajar yang lebih baik lagi, sehingga menjadi dorongan kepada anak-anak asuh yang hasil belajarnya kurang memuaskan untuk terus belajar yang lebih giat untuk meraih hasil belajar yang lebih baik. Untuk mendapatkan hadiah tersebut anak asuh harus melakukan sesuatu yang disuruh pengasuh yaitu belajar dengan rajin dan mendapatkan nilai yang baik, cara yang digunakan oleh pengasuh sesuai dengan pendapat Schaefer, bahwa memberikan hadiah pada anak dengan membuat suasana yang menyenangkan (Dalyono dan Slameto, 2011).

Motivasi yang diberikan pengasuh, membuat anak asuh belajar keras agar dapat meraih prestasi yang memuaskan, dari hasil belajar yang tekun dan gigih, anak asuh mampu memperlihatkan kepada banyak orang bahwa mereka layak mendapatkan hasil belajar tinggi. Prestasi belajar yang tinggi merupakan impian setiap peserta didik yang sedang belajar di suatu lembaga pendidikan. Hemat peneliti, impian memiliki masa depan yang baik, menjadi penyemangat dan mesin untuk 
membangkitkan kemauan besar mencapai cita-cita dan mengejar impian menjadi orang yang sukses.

Sedangkan nonformal pengasuh membekali mereka dengan kegiatan-kegiatan berupa qasidah sebagai pembentukan mental, sehingga ketika ada perlombaan maka pihak pengasuh mengikut sertakan mereka dalam perlombaan tersebut sehingga mereka meraih prestasi berupa juara satu.

\section{KESIMPULAN}

Banyak bentuk aktualisasi peran pengasuh dalam mendidik dan membina serta mendorong anak asuh agar menjadi orang yang bermanfaat kepada masyarakat, bangsa dan negara. Penanaman nilai-nilai keagamaan yang kuat dan sistematis ditujukan untuk menyiapkan anak asuh agar dapat berperan penting bagaimana layaknya peran-peran orang dengan latar belakang bukan anak asuh dalam Panti Asuhan. Oleh karena itu, motivasi yang diberikan pengasuh, membuat anak asuh belajar keras agar dapat meraih prestasi yang memuaskan, dari hasil belajar yang tekun dan gigih, anak asuh mampu memperlihatkan kepada banyak orang bahwa mereka layak mendapatkan hasil belajar tinggi. Prestasi belajar yang tinggi merupakan impian setiap peserta didik yang sedang belajar di suatu lembaga pendidikan. Hemat peneliti, impian memiliki masa depan yang baik, menjadi penyemangat dan mesin untuk membangkitkan kemauan besar mencapai cita-cita dan mengejar impian menjadi orang yang sukses.

\section{DAFTAR PUSTAKA}

[1] Arifin, Zainal. Evaluasi Intruksional Prinsip-prinsip Prosedur, Bandung : Remaja Rosdakarya, 1991.

[2] Aunurrahman, Belajar dan Pembelajaran, Bandung : Alfabeta, 2014.

[3] Dalyono dan Slameto, Bentuk-Bentuk Perhatian Pengasuh, Bandung : CV Pustaka Setia 2011.

[4] Khodijah, Nyayu. Psikologi Pendidikan, Jakarta : Raja Grafindo Persada, 2014.

[5] Pedoman Depsos Rl, Buku Petunjuk Pelaksanaan Penyantunan dan Pengentasan Anak Melalui Panti Asuhan, Jakarta : Balai Pustaka, 1986.

[6] Pelupessy, Nur Khozin Abdullah, and Saddam Husein. "PEMBINAAN AKHLAK MULIA MAHASISWA DALAM LEMBAGA DAKWAH KAMPUS (LDK) AL-IZZAH IAIN AMBON." al-IItizam: Jurnal Pendidikan Agama Islam 3.1 (2018): 53-64.

[7] Ramyulis, Khatib. Pendidikan Islam dalam Rumah Tangga, Jakarta : Kalam Mulia, 1996.

[8] Sardiman, Interaksi dan Motivasih Belajar Mengajar, Jakarat : PT Raja Grafindo Persada 2012.

[9] Sunartik, Pola Pengasuh Anak Secara Tradisional, Jakarta : PT Raja Grafindo Persada, 1989. 